\title{
Investigation of Neutrophil-to-lymphocyte Ratio as a Biomarker to Evaluate Systemic Inflammation in Clinical Otosclerosis
}

\section{Klinik Otosklerozda Sistemik Enflamasyonu Değerlendirmek için Biyobelirteç Olarak Nötrofil Lenfosit Oranının Araștırılması}

\author{
(1) Hasan Deniz Tansuker, (1) Cemal Özyılmaz, (1) Abdurrahman Buğra Cengiz, (1) Mehmet Faruk Oktay \\ İstanbul Bağcılar Training and Research Hospital, Clinic of Otolaryngology, İstanbul, Turkey
}

\begin{abstract}
Introduction: Otosclerosis with yet unexplained etiopathogenesis, especially for inflammatory mechanism, affects otic capsule of ear and causes progressive hearing loss.

We aimed to investigate whether there is systemic inflammation in patients with otosclerosis by measuring neutrophil-tolymphocyte ratio (NLR) as a biomarker.

Methods: This retrospective study included 98 patients which were divided into 2 groups as clinical otosclerosis and control group. The otosclerosis group consisted of 49 patients who stapes fixation was confirmed during operation based on operative notes and underwent surgery for otosclerosis from January of 2015 to November of 2018. The control group consisted of 49 age and sex-matched subjects who were scheduled for septoplasty or septorhinoplasty, who did not have any otologic complaints, and who had normal otologic examination. In both group of the patients white blood cell count (WBC), neutrophil and lymphocyte counts, and other laboratory data were recorded; and NLR values were calculated from their pre-op complete blood cell count differentials. Age, gender, WBC, neutrophil, lymphocyte, and NLR values were compared between the groups to evaluate any correlations in between.
\end{abstract}

Results: For the mean NLR, there was not a statistically significant difference between the groups $(p=0.143)$. WBC comparison of the groups showed no statistically significance $(p=0.315)$. For average neutrophil and lymphocyte counts, there were not a statistically significant difference between the groups; $(p=0.757)$ and $(p=0.071)$, respectively.

Conclusion: Although NLR is related to the prognosis and severity of several diseases, we found no association with clinical otosclerosis in this study. The reasons of insignificant results are thought to be that otosclerosis does not cause a systemic inflammation at all or the patients were in the inactive period of the disease.

Keywords: Otosclerosis, systemic inflammation, biomarker, neutrophil-to-lymphocyte ratio öz

Amaç: Otik kapsülü etkileyerek önemli bir ilerleyici işitme kaybı hastalığı olan otosklerozun etiyopatogenezini açıklayabilecek çeșitli mekanizmalar öne sürülmüş olup sistemik enflamasyon bunlardan birisidir.

Biz bu çalışmamızda otoskleroz hastalarındaki nötrofil/lenfosit oranını (NLO) ölçerek otosklerozun olası etiyolojik faktörlerden birisi olarak kabul edilen sistemik enflamasyonun varlığını araștırmayı amaçladık.

Yöntemler: Bu retrospektif çalıșma 98 hastayı içermektedir. Hastalar klinik otosklerozu olanlar ve kontrol hastaları olarak 2 gruba ayrıldı. Otoskleroz grubu, hastanemizde 2015 Ocak2018 Kasım tarihleri arasında otoskleroz ameliyatı geçirerek stapes fiksasyonu ameliyat notaları incelenerek teyit edilmiş 49 hastadan oluştu. Kontrol grubu, hastanemizde septoplasti veya septorinoplasti operasyonu planlanmış, otolojik şikayeti olmayan ve otolojik muayenesi normal olan, yas ve cinsiyetleri otoskleroz grubu ile aynı 49 hastadan oluşturuldu. Her iki grupta da ameliyat öncesi yapılan rutin hemogram tetkiklerinden lökosit, nötrofil ve lenfosit sayıları ve diğer laboratuvar verileri kaydedilerek NLO değerleri hesaplandı. Yaş ve cinsiyet; lökosit, nötrofil ve lenfosit sayıları ile NLO değerleri ortalamaları gruplar arasında karșılaștırılarak aradaki ilișki değerlendirildi.

Bulgular: Ortalama NLO için gruplar arasında fark olmakla birlikte bu fark istatistiksel açıdan anlamlı değildi ( $p=0.143$ ). Ortalama lökosit sayısı açısından gruplar arasında fark olmakla birlikte bu fark da istatistiksel açıdan anlamlı değildi ( $p=0.315)$. Aynı şekilde ortalama nötrofil ve özellikle lenfosit sayıları için gruplar arasında fark olmakla birlikte bu farklar istatistiksel açıdan anlamlı değildi; sırasıyla $(p=0.757)$ ve $(p=0.071)$.

Sonuç: NLO'nun enflamatuvar bileșeni olan birçok hastalığın prognozu ve șiddeti ile ilişkisi literatürde gösterilmiş olmasına rağmen, biz bu çalışmada klinik otoskleroz ile istatistiksel açıdan anlamlı bir ilişkisini gözlemlemedik. Biz bu sonuçlara göre, otosklerozun sistemik bir enflamasyona neden olmadığını ya da hastaların otosklerozun histopatolojik olarak inaktif döneminde olduklarını düşünmekteyiz.

Anahtar Kelimeler: Otoskleroz, sistemik inflamasyon, biyobelirteç, nötrofil lenfosit oranı

(c) Copyright 2019 by the Istanbul Training and Research Hospital/istanbul Medical Journal published by Galenos Publishing House. 


\section{Introduction}

Otosclerosis is a bone remodeling disorder of the human bony inner ear leading to progressive hearing loss that usually affects both ears with yet unexplained etiopathogenesis. It is a unique human disease with no animal model at all. It does not have any lesion or any systemic clue other than the ear. Genetic predisposition, viral infection, autoimmunity, inflammatory mechanisms, hormonal and metabolic factors have been blamed for the pathogenesis of the disease. Some proinflammatory cytokines have been studied to investigate the inflammatory mechanism of otosclerosis (1).

Systemic inflammation can be measured by using a variety of biochemical and hematological markers. Neutrophil-to-lymphocyte ratio (NLR) has been recognized as a systemic inflammatory marker in recent years. Since high NLR correlates with the severity of the inflammation, it can help predict clinical outcomes for many systemic diseases. NLR has also been studied in various autological disorders such as Bell's palsy (BP), sudden hearing loss, tinnitus, chronic otitis media (COM) (2). In contrast to many inflammatory cytokines, determination of NLR is a very practical and readily available way to detect inflammation without extra cost because it can be easily calculated from a simple complete blood cell count (CBC) (3).

In this study, we aimed to investigate whether there is ongoing systemic inflammation in patients with clinical otosclerosis. By doing so, we hoped to help clarify one of the suspected etiopathogenetic factors of otosclerosis by measuring NLR as an inexpensive, simple and reproducible testing method. To the best of our knowledge, this is the first study in the literature to investigate serum NLR in patients with otosclerosis.

\section{Methods}

This study is a retrospective investigation of the data obtained from the digital patient files. This study was performed with the approval of the Clinical Research Ethics Committee of İstanbul Bağcılar Training and Research Hospital (approval number: 2019.01.2.04.119.r1.008). This study included 98 patients, who were divided into two groups as clinical otosclerosis and control group. The otosclerosis group consisted of 49 patients with confirmed stapes fixation during surgery based on operative notes and underwent surgery for otosclerosis (eg. Stapedectomy) between December 2014 and November 2018 at the Department of Otolaryngology at İstanbul Bağcılar Training and Research Hospital. Tympanic membranes of the patients were intact and there was no hyperemia or any other infection sign in the preoperative otoscopic examination. In these patients, white blood cell count (WBC), neutrophil and lymphocyte counts, and other laboratory data were recorded; and NLR values were calculated from pre-op CBC differentials by dividing neutrophil count by lymphocyte count.

The control group consisted of 49 age- and gender-matched subjects who were scheduled for septoplasty or septorhinoplasty in our hospital, who did not have any otologic complaints, and who had a normal otologic examination. They underwent blood count analysis from which the same hematological parameters described above were recorded and calculated from. Age, gender, WBC, neutrophil and lymphocyte counts and NLR values were compared between the groups to evaluate any correlations in between. Patients with history or clinical findings of any acute or chronic infectious, inflammatory or systemic disease that could have an effect on blood counts according to strict literature review were excluded from the study completely.

\section{Statistical Analysis}

SPSS (Version 15) program was employed for evaluating the data gathered in the study. Besides using descriptive statistics (mean, standard deviation) in evaluating the data, independent samples t-test was used for comparing the quantitative data, and for comparing the normally distributed parameters between groups. The significance level was set at $p<0.001$ and $p<0.05$.

\section{Results}

This study included 98 patients [28 females (28.6\%) and 70 males (71.4\%)] with a mean age of $37.79 \pm 10.84$ years. Otosclerosis group consisted of 49 patients with a mean age of $37.85 \pm 9.72$ years. The control group consisted of 49 patients with a mean age of $37.73 \pm 11.96$ years. There was no statistically significant difference between the groups in terms of mean ages and genders $(p=0.235)$ (Table 1).

The mean NLR of the otosclerosis and the control group was $1.99 \pm 0.78$ and $1.76 \pm 0.55$, respectively. The independent samples t-test showed no statistically significant difference between the groups $(p=0.143)$. The mean WBC level was $7.15 \pm 1.87$ in the otosclerosis group and $7.43 \pm 1.88$ in the control group. WBC comparison of the groups showed no statistical significance $(p=0.315)$.

The average neutrophil counts of the otosclerosis and the control groups were $4.16 \pm 1.47$ and $4.14 \pm 1.23$, respectively $(p=0.757)$. The mean lymphocyte counts of the otosclerosis and the control groups were $2.22 \pm 0.64$ and $2.46 \pm 0.74$, respectively $(p=0.071)$. The independent samples t-test showed that there was no statistically significant difference between the groups (Table 2).

\begin{tabular}{|c|c|c|c|}
\hline & \multicolumn{2}{|l|}{ Patient } & \multirow[t]{2}{*}{ Age } \\
\hline & Male & Female & \\
\hline Otosclerosis group & $14(28.6 \%)$ & 35 (71.4\%) & $37.85 \pm 9.72$ \\
\hline Control group & $14(28.6 \%)$ & 35 (71.4\%) & $37.73 \pm 11.96$ \\
\hline \multirow[t]{2}{*}{ Total } & 28 & 70 & $37.79 \pm 10.84$ \\
\hline & & & $p=0.235$ \\
\hline
\end{tabular}

Table 2. Laboratory data of the groups. The independent sample t-test, $\mathbf{p}<0.05$

\begin{tabular}{|l|l|l|l|}
\hline & $\begin{array}{l}\text { Otosclerosis } \\
\text { group }\end{array}$ & $\begin{array}{l}\text { Control } \\
\text { group }\end{array}$ & p \\
\hline WBC & $7.15 \pm 1.87$ & $7.43 \pm 1.88$ & 0.315 \\
\hline Neutrophil $\left(10^{3} / \mu\right)$ & $4.16 \pm 1.47$ & $4.14 \pm 1.23$ & 0.757 \\
\hline Lymphocyte $\left(10^{3} / \mu\right)$ & $2.22 \pm 0.64$ & $2.46 \pm 0.74$ & 0.071 \\
\hline $\begin{array}{l}\text { Neutrophil to Lymphocyte } \\
\text { Ratio }\end{array}$ & $1.99 \pm 0.78$ & $1.76 \pm 0.55$ & 0.143 \\
\hline WBC: white blood cell & & & \\
\hline
\end{tabular}




\section{Discussion}

Although less than $0.5 \%$ of the general population develops clinical otosclerosis, the development of histological otosclerosis without clinical symptoms is much more common, which is reported in about $10 \%$ of large autopsy series (4). Because inflammatory mechanism has also been one of the blamed factors of the disease, an antiinflammatory therapy may be considered to control early active phases of otosclerosis (1). Approximately 5000 studies have been published based on the pathology and treatment of otosclerosis in the last 5 decades. In the second half of this period, more than 1500 articles have been published, while only about 100 publications provided data on the etiopathogenesis of the disease; so that the etiopathogenesis of otosclerosis yet remains unexplained. Viral, genetic, inflammatory, autoimmune, environmental, hormonal and some other factors have been blamed in both the development and the progression of the disease (1). Some molecules such as transforming growth factor-beta (TGF- $\beta 1$ ), tumor necrosis factor-alpha (TNF- $\alpha$ ), and bone morphogenetic proteins (BMP) have been studied to reveal the suspected relationship between the inflammatory mechanism and otosclerosis. TGF- $\beta 1$ is a cytokine involved in the pathogenesis of various inflammatory diseases and associated with otosclerosis in some studies (5). Increased expression of TNF- $\alpha$, which is a proinflammatory cytokine, has been demonstrated in the otosclerotic bone. It may lead to extensive osteoclast activation and bone resorption $(6,7)$. BMP, which has been suggested to play a role in pathological bone remodeling underlying otosclerosis, is also an inflammatory cytokine (1).

The NLR, combining the deleterious effects of neutrophilia and lymphopenia, is now recognized as a systemic inflammatory marker (8). In contrast to other inflammatory biomarkers such as interleukin-6 (IL6), IL-1 $\alpha$, TNF- $\alpha$, determination of NLR does not incur any additional cost. It can easily be calculated from the neutrophil and lymphocyte counts available from routine CBC differentials (9). In several studies, an association has been found between a high NLR level and the prognosis and severity of disease in several cancers, and in inflammatory diseases such as BP and sudden hearing loss (10-13).

In recent studies, NLR has been identified as a reliable marker for the diagnosis and prediction of many ORL diseases. Özler and Günak (14) showed that mean NLR values were significantly higher in patients with BP than in the control group. They described a positive correlation between NLR values and the grade and prognosis of BP. Kılıçkaya et al. (15) investigated the systemic inflammatory effect of COM with cholesteatoma and showed that NLR had no predictive value with respect to bone erosions and associated complications in patients with cholesteatoma. Eryilmaz and Derin (16) studied the NLR values in pediatric patients and compared with those in COM with and without cholesteatoma. There was no statistically significant difference between the two groups in terms of NLR. However, mean platelet volume was lower in patients with cholesteatoma than controls, which they suggested could act as a predictor for cholesteatoma. When 247 patients with sensory neural hearing loss (SHL) were compared according to the recovery, Ulu et al. (17) reported that NLR levels were higher in patients who did not recover. This may be explained with the higher inflammatory situation in unrecovered patients, and this result may help clinicians caring for SHL patients with higher NLR levels in terms of treatment and prognosis. Kum et al. (10) reported that NLR values were significantly higher in patients with SHL compared to the control group. Similarly, the mean NLR was higher in the unrecovered patients when compared with those who recovered; a significant correlation was observed between NLR values and the severity of hearing loss, indicating inflammation. Atan et al. (18) conducted a study with 77 patients and showed that NLR was high in OME. In another study, NLR was similarly higher in OME patients compared with the control group, and this finding showed the importance of the inflammation in the pathophysiology of OME (4).

In summary, NLR is an easily measured biomarker that correlates with clinical status. It is calculated from CBC and is an inexpensive, easy to obtain, a widely available marker of inflammation that can help in the risk classification of patients with various diseases $(19,20)$. It is as valuable as many other high-cost inflammatory markers (9). For these reasons, we measured NLR, neutrophil, lymphocyte and WBC counts in patients with otosclerosis and compared to values in the control group in both agematched and gender-matched manner to investigate whether there is a systemic manifestation in the disease process and inflammatory factor in the etiopathogenesis. To the best of our knowledge, the present study is the first to assess the NLR values in patients with otosclerosis. While an increase in NLR is expected in inflammatory diseases, we found no increase in NLR and WBC counts in patients with otosclerosis that may demonstrate that no systemic reaction is produced by the disease. Another reason why the result is not significant might be that the otosclerosis group was not in the active inflammation period of the disease process. The limitation of our study was the lack of a group of patients with active inflammation. However, it is very difficult to catch and create such a group of otosclerosis patients in clinical practice.

\section{Conclusion}

Although NLR is related to the prognosis and severity of several diseases, we found no association with clinical otosclerosis in this study. The reasons for insignificant results are thought to be that otosclerosis does not cause a systemic inflammation at all or the patients were in the inactive period of the disease. Further studies will be beneficial to clarify these.

Ethics Committee Approval: This study was performed with the approval of the Clinical Research Ethics Committee of İstanbul Bağcılar Training and Research Hospital (approval number: 2019.01.2.04.119. r1.008).

Informed Consent: Retrospective study.

Peer-review: Externally peer-reviewed.

Author Contributions: Surgical and Medical Practices - H.D.T., M.F.O.; Concept - H.D.T., M.F.O.; Design - H.D.T.; Data Collection and/or Processing - HC.Ö., A.B.C.; Analysis and/or Interpretation - C.Ö., A.B.C.; Literature Search - C.Ö.; Writing Manuscript - H.D.T., A.B.C.; Conflict of Interest: No conflict of interest was declared by the authors.

Financial Disclosure: The authors declared that this study received no financial support. 


\section{References}

1. Karosi T, Sziklai I. Etiopathogenesis of otosclerosis. Eur Arch Otorhinolaryngol 2010; 267: 1337-49.

2. Yiğit E, Önerci Çelebi Ö, Server EA, Longur ES. Neutrophil-to-lymphocyte ratio and mean platelet volume in chronic otitis media with or without cholesteatoma. Istanbul Med J 2018; 19: 162-6.

3. Elbistanli MS, Koçak HE, Acipayam H, Yiğider AP, Keskin M, Kayhan FT. The predictive value of neutrophil-lymphocyte and platelet-lymphocyte ratio for the effusion viscosity in otitis media with chronic effusion. J Craniofac Surg 2017; 28: 244-7.

4. Declau F, Van Spaendonck M, Timmermans JP, Michaels L, Liang J, Qiu JP, et al. Prevalence of otosclerosis in an unselected series of temporal bones. Otol Neurotol 2001; 22: 596-602.

5. Thys M, Schrauwen I, Vanderstraeten K, et al. The coding polymorphism T263I in TGF-beta1 is associated with otosclerosis in two independent populations. Hum Mol Genet 2007; 16: 2021-30.

6. McKenna MJ, Kristiansen AG. Molecular biology of otosclerosis. Adv Otorhinolaryngol 2007; 65: 68-74

7. Karosi T, Konya J, Szabo LZ, Pytel J, Jóri J, Szalmás A, et al. Codetection of measles virus and tumor necrosis factor- alpha mRNA in otosclerotic stapes footplates. Laryngoscope 2005; 115: 1291-7.

8. Roxburgh CS, McMillan DC. Role of systemic inflammatory response in predicting survival in patients with primary operable cancer. Future Oncol 2002; 6: 149-63.

9. Turkmen K, Guney I, Yerlikaya FH, Tonbul HZ. The relationship between neutrophil-to-lymphocyte ratio and inflammation in end-stage renal disease patients. Ren Fail 2012; 34: 155-9.

10. Fang HY, Huang XY, Chien HT, Chang JT, Liao CT, Huang J], et al. Refining the role of preoperative C-reactive protein by neutrophil/lymphocyte ratio in oral cavity squamous cell carcinoma. Laryngoscope 2013; 123: 2690-9.
11. Kum RO, Ozcan M, Baklaci D, Yurtsver Kum N, Yilmaz YF, Unal A, et al. Investigation of neutrophil-to-lymphocyte ratio and mean platelet volume in sudden hearing loss. Braz J Otorhinolaryngol 2015; 81: 636-41.

12. Wong BY, Stafford ND, Green VL, Greenman J. Prognostic value of the neutrophil-to-lymphocyte ratio in patients with laryngeal squamous cell carcinoma. Head Neck 2016; 38: 1903-8.

13. Graziosi L, Marino E, De Angelis V, Rebonato A, Cavazzoni E, Donini A. Prognostic value of preoperative neutrophils to lymphocytes ratio in patients resected for gastric cancer. Am J Surg 2015; 209: 333-7.

14. Özler GS, Günak G. Neutrophil-lymphocyte ratio: A new predictive and prognostic factor in patients with bell palsy. J Craniofac Surg 2014; 25: 944-5.

15. Kılıçkaya MM, Aynali G, Tuz M, Bagcı Ö. Is there a systemıc inflammatory effect of cholesteatoma? Int Arch Otorhinolaryngol 2017; 21: 42-5.

16. Eryilmaz, MA, Derin S. Mean platelet volume as a potential predictor of cholesteatoma in children. J Craniofac Surg 2016; 27: 575-8.

17. Ulu S, Ulu MS, Bucak A, Ahsen A, Yucedag F, Aycicek A. Neutrophil-tolymphocyte ratio as a new, quick, and reliable indicator for predicting diagnosis and prognosis of idiopathic sudden sensorineural hearing loss. Otol Neurotol 2013; 34: 1400-4

18. Atan D, Apaydin E, Ozcan KM, Dere H. New diagnostic indicators in chronic otitis media with effusion: neutrophil to lymphocyte ratio and thrombocyte lymphocyte ratio. ENT updates 2016; 6: 12-5.

19. Paramanathan A, Saxena A, Morris DL. A systematic review and meta-analysis on the impact of pre-operative neutrophil lymphocyte ratio on long term outcomes after curative intent resection of solid tumours. Surg Oncol 2014; 23: $31-9$.

20. Szkandera J, Gerger A, Liegl-Atzwanger B, Absenger G, Stotz M, Friesenbichler J, et al. The lymphocyte/monocyte ratio predicts poor clinical outcome and improves the predictive accuracy in patients with soft tissue sarcomas. Int J Cancer 2014; 135: 362-70. 